\title{
APLIKASI KAIN TENUN SUMBA PAHIKUNG PADA BUSANA READY TO WEAR
}

\author{
APPLICATION OF TRADITIONAL WOVEN FABRIC SUMBA PAHIKUNG IN \\ READY TO WEAR CLOTHING
}

\author{
Tina Martina ${ }^{1}$, Wine Regyandhea Putri ${ }^{2}$, Irfandhani Fauzi ${ }^{2}$ dan Haifa B ilqis ${ }^{3}$ \\ 1. Dosen Politeknik STTT Bandung, Indonesia \\ 2. Staf Pengajar Politeknik STTT Bandung, Indonesia \\ 3. Mahasiswa Politeknik STTT Bandung \\ Produksi Garmen, Politeknik STTT Bandung, 40272, Indonesia \\ E-mail: martina12sttt@gmail.com; reyandheawine@yahoo.com; \\ fauzi.fandhani@gmail.com; haifabilqis@gmail.com
}

\begin{abstract}
ABSTRAK
Tenun merupakan salah satu warisan budaya tinggi kebanggaan dan jati diri bangsa Indonesia. Oleh sebab itu, tenun baik dari segi teknik produksi, desain dan produk yang dihasilkan harus dijaga dan dilestarikan keberadaannya, serta dimasyarakatkan penggunaannya. Salah satu daerah yang tetap melestarikan kain tenun yaitu Sumba Pahikung. Untuk lebih mengenalkan pada khalayak dan melestarikan kain tenun Sumba Pahikung, maka disusun rencana penelitian ini yang bertujuan untuk mengangkat dan mengembangkan muatan lokal Sumba berupa ragam hias yang diaplikasikan pada busana ready to wear. Desain perancangan busana ready to wear yang memiliki inspirasi warna dan garis desain dengan tema Vigilant dari Trend Forecasting Greyzone Fashion 2017-2018 Bekraf. Produk pakaian jadi dengan aplikasi kain tenun Sumba Pahikung akan dinilai secara ekonomi serta dengan metode kuantitatif berupa kuisioner yang disebar ke masyarakat akan dianalisa kelayakan harga dan kualitas yang dihasilkan. Dua desain busana ready to wear yang dibuat dapat diterima masyarakat secara kualitas disain etnik, akan tetapi saat dinilai secara harga masih ada sedikit perbedaan dengan perhitungan biaya produksinya.
\end{abstract}

Kata kunci: Tenun Sumba Pahikung, Ready To Wear, Trend Forecasting, Fashion

\begin{abstract}
Weaving is one of the high cultural heritage of Indonesian pride and identity. Therefore, both in terms of production techniques, designs and products must be maintained and preserved, and also popularized its use. One area that continues to preserve the woven fabric is Sumba Pahikung. This research is made in order to further introduce and preserve the woven fabric of Sumba Pahikung. The objective is to raise and develop local content of Sumba in the form of decoration that is applied to ready to wear clothing. The ready to wear clothing has color inspiration and design lines with Vigilant theme from Bekraf Trend Forecasting Greyzone Fashion 2017-2018. The products will be assessed economically with quantitative methods in the form of questionnaires distributed to the public. This will be analyzed the quality and feasibility of price. The result is quality of the product of ready to wear are acceptable to the public, although for the price there is little difference with the calculation of production costs.
\end{abstract}

Keywords: Sumba Pahikung Weaving, Ready To Wear, Trend Forecasting, Fashion 


\section{PENDAHULUAN}

\subsection{Latar B elakang}

Sejak jaman pra sejarah nenek moyang bangsa Indonesia telah mengenal teknik menenun. Tenun merupakan salah satu karya seni budaya kain tradisional Indonesia yang diproduksi di berbagai wilayah Nusantara seperti di Sumatera, Kalimantan, Bali, Sulawesi, Nusa Tenggara Timur dan Sumbawa. Tenun memiliki makna, nilai sejarah, dan teknik yang tinggi dari segi warna, motif, dan jenis bahan serta benang yang digunakan dan tiap daerah memiliki ciri khas masingmasing yang sering kali dikaitkan dengan kearifan lokal serta kepercayaan dan adat istiadat yang dianut penduduk setempat. Pada proses pembuatannya, tenun memilki beragam teknik seperti ikat pakan, ikat lusi, teknik songket, pakan dan lusi tambah, pilin, tenun kartu, dan taperstri.

Kain tenun Sumba sangat terkenal karena keindahannya. Pada sehelai kain Sumba tercermin aspek lingkungan alam dan gaya kehidupan masyarakatnya. Terdapat dua daerah penghasil tenun ikat di Sumba yaitu Sumba Timur dan Sumba Barat. Sumba Timur dikenal dengan ragam hias fauna dan Sumba Barat dikenal dengan ragam hias yang cendrung geometris. Beberapa ragam hias khas Sumba adalah kuda dan rusa. Corak kuda pada kain adat Sumba digambarkan dalam macam-macam perilaku, misalnya dengan mengangkat satu kaki ke atas, ke belakang, dan lainnya. Ragam hias lainnya adalah pohon andung atau sering disebut 'pohon tengkorak'. Tengkorak yang tampak tegantung pada dahan-dahannya adalah penggambaran dari tengkorak penjahat yang ditaklukkan, kemudian digantungkan pada pohon lontar yang ditanam di halaman pintu gerbang desa. Umumnya, terdapat delapan kepala dalam satu pohon. Hal ini dihubungan dengan kepercayaan setempat yang menceritakan bahwa nenek moyang mereka sebelum sampai di Sumba, singgah terlebih dahulu di delapan tempat.

Tenun Sumba Pahikung merupakan tenun yang berasal dari daerah Sumba Timur, Nusa Tenggara Timur, yang memiliki keistimewaan lain dibanding dengan tenun lainnya, karena pada saat proses pengerjaanya kain tenun tersebut juga diberikan teknik lusi tambahan. Motif yang terdapat pada kain pahikung memilki ciri khas berupa motif geometris berbentuk belah ketupat, bentuk garis, dan titik pada sisi-sisi kain serta terdapat motif berbentuk manusia, kuda, ikan dan udang pada bagian tengah kain. Corak yang dihasilkan timbul di atas permukaan kain, mirip seperti corak sulam.

Kain tenun Sumba Pahikung memiliki berbagai macam warna dari warna gelap hingga terang dan hanya memilki motif pada satu sisi kain saja. Keunikan teknik pembuatan serta motif kain tenun memiliki daya tarik tersendiri bagi penikmat fashion sehingga banyak para desainer lokal yang mengangkat kain warisan Nusantara sebagai bagian dari rancangan desain. Rancangan busana desainer dapat berupa adibusana ataupun ready to wear. Mahalnya harga rancangan desainer menyebabkan masyarakat enggan membeli busana dengan aplikasi kain tenun. Oleh karena itu, pengaplikasian tenun perlu dibuat dalam rancangan ready to wear dengan harga yang lebih terjangkau agar tenun Sumba Pahikung lebih dikenal dan diminati oleh masyarakat luas dan harganya pun perlu disesuaikan dengan konsep busana ready to wear. Pada dua rancangan hasil penelitian desain pakaian ready to wear digunakan detail kepang dari kain utama sebagai hiasan dengan sentuhan konvensional dengan membuat jalinan antar kain sehingga tampak seperti tambang atau tali yang dikepang untuk memperindah tampilan dan mempertegas batas antara aplikasi kain tenun dengan bahan atau kain utama busananya.

Penelitian juga dilakukan untuk menilai kualitas kain busana ready to wear. Dalam memilih kain untuk tujuan tertentu biasanya diperlukan karakteristik-karakteristik yang sesuai dengan pemakaiannya. Anyaman menjadi salah satu faktor dalam kontruksi kain tenun selain tetal benang, crimp, nomor benang dan berat kain. Apabila kain-kain tersebut digunakan untuk kebutuhan teknik atau industri maka diperlukan informasi mengenai kekuatan, mulur, ketahanan terhadap zat-zat kimia tertentu dan sebagainya. Jika kain tersebut digunakan untuk pakaian, selain sifat-sifat teknis tersebut, sifat-sifat lain yang diuji beberapa sifat yang sulit ditunjukan dalam angka-angka seperti kenampakan, kilau, kehaluasan atau kekasaran, kekakuan atau kelemasan, dan mutu draping. 
Pemilihan kain biasanya dilakukan dengan memegang dan mencoba kainnya kemudian ditentukan mana yang sesuai dengan keperluannya. Dengan cara ini maka penilaian bersifat subyektif. Apabila pegangan kain ditentukan, maka mencakup rasa baku atau lembek, keras atau lunak, dan kasar atau halus.

Drape memiliki pengertian yaitu kemampuan kain untuk memberikan kenampakan indah waktu dipakai. Tidak semua bahan pakaian harus mempunyai drape yang baik. Untuk menentukan pegangan dan drape ada dua hal utama yang dilakukan, pertama pemisahan macam-macam bahan yang memiliki pegangan dan drape, dan desain instrumen yang cocok untuk mengukur sifat-sifat kain secara individu. Kedua menggunakan teknik-teknik statistik untuk menemukan kesimpulan mengenai hubungan antara hasil-hasil pengujian yang dinilai individu dan secara grup oleh para penilai.

\subsection{Maksud dan Tujuan Penelitian}

Maksud: Penggunaan kain tenun sumba Pahikung dapat diterima masyarakat

Tujuan : Menganalisa pendapat masyarakat akan penggunakan kain tenun sumba Pahikung dalam bentuk desain busana ready to wear.

\subsection{Identifikasi Masalah}

Apakah desain busana ready to wear dengan penggunakan aplikasi kain tenun Sumba Pahikung dapat diterima oleh masyarakat?

\subsection{Manfaat Penelitian}

Manfaat yang akan diperoleh dari hasil penelitian ini bagi para pelaku industri (IKM Pertenunan) adalah lebih berkembangnya penggunaan kain tenun dengan implikasi akan meningkatnya permintaan produk ataupun penjualan kain tenunnya.

Adapun manfaat bagi masyarakat adalah dapat meningkatkan minat masyarakat dalam pengembangan atau diversifikasi produk dari kain tenun tradisional Sumba Pahikung

\section{METODA PENELITIAN}

\subsection{Alat dan Bahan}

Alat yang digunakan pada penelitian ini adalah peralatan menjahit; gunting, meteran ukur, mesin jahit dan obras. Bahan yang digunakan dalam penelitian ini adalah kain tenun Sumba Pahikung, kain Dutches, kain interlining, ritsleting metal serta manik-manik. 


\subsection{Metode}

Penelitian ini mengunakan metode studi pustaka serta pembuatan produk. Sedangkan untuk harga yang sesuai dengan produk akhir digunakan metode kualitatif dengan penyebaran kuisioner. Adapun tahapan penelitian ini adalah:

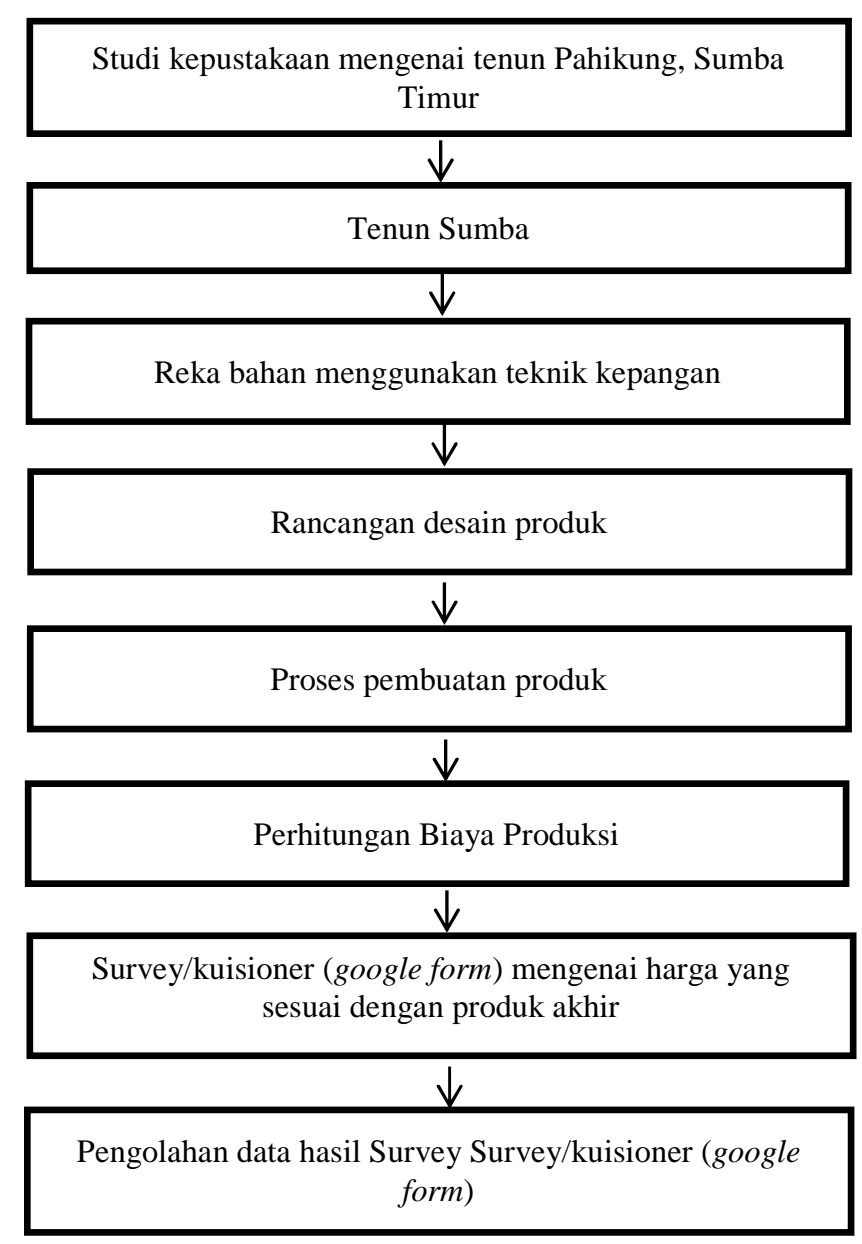

Gambar 1. Metoda Penelitian

\section{HASIL DAN PEMBAHASAN}

Produk akhir dari busana ready to wear dari kain Tenun Sumba Pahikung telah melalui berbagai proses perancangan, pembuatan, dan pengedalian mutu produk serta setelah melakukan proses photoshoot yang bertujuan sebagai pemasaran produk kepada masyarakat dapat dilihat pada Gambar 2. 

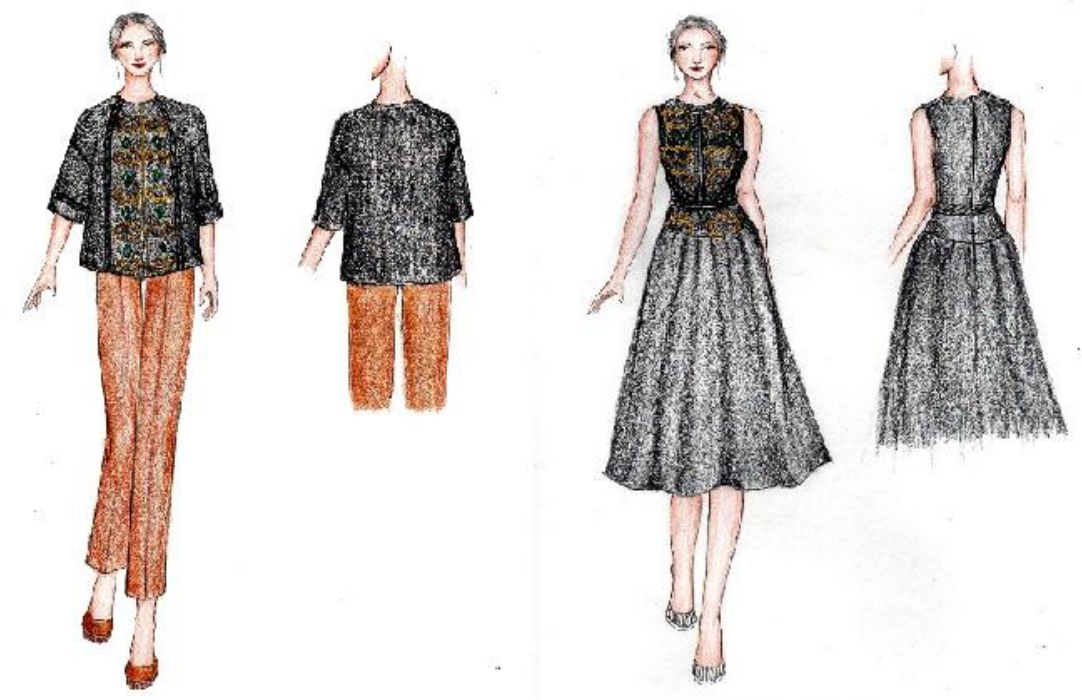

Gambar 2. Rancangan Busana Ready To Wear Sumba Pahikung

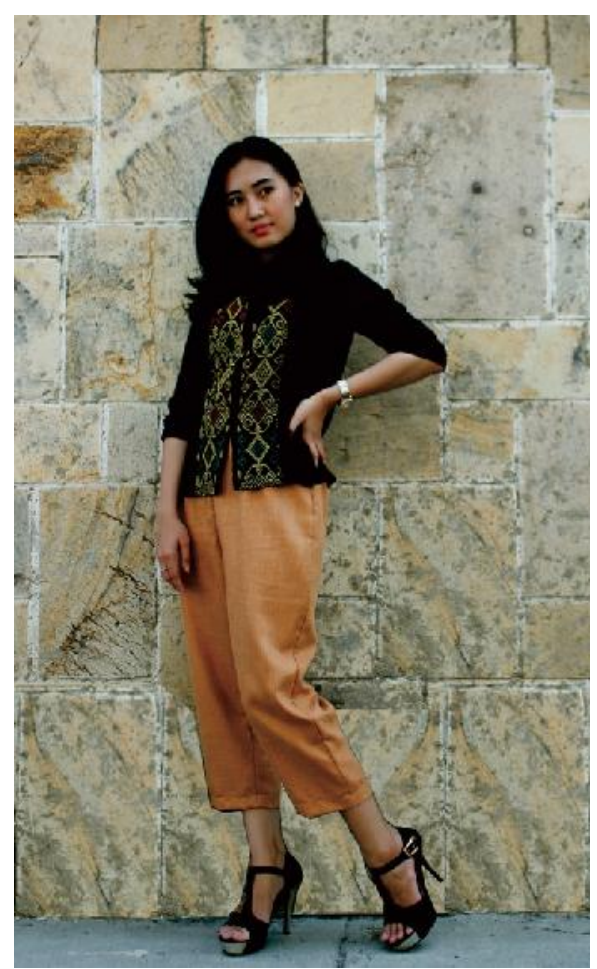

Gambar 3. Produk Sumba Pahikung 1

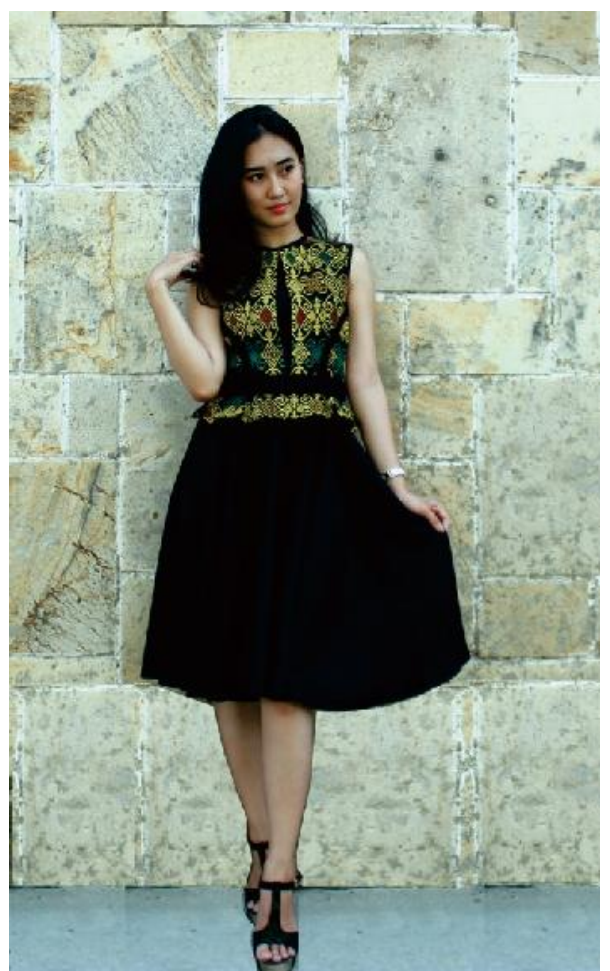

Gambar 4. Produk SumbaPahikung 2

Pemilihan kain yang digunakan pada penelitian ini juga dilakukan pengujian karekteristik dari kain yang digunakan sebagai bahan busana ready to wear. Maksud dari dilakukannya pengujian karakteristik adalah untuk memperkuat data bahwa pemilihan kain yang digunakan sesuai dengan tujuan akhir / end use yang ingin diperoleh dari tampilan busananya, misalnya untuk bahan baku kain rok bagian bawah desain Sumba Pahikung 2 memerlukan bahan dengan nilai drape yang baik sedangkan pengujian tebal dan berat kain akan berhubungan dengan drape / kelangsaian kain. Adapun pengujian kekuatan tarik kain dimaksudkan untuk menilai kekuatan 
kain saat dilakukan penggabungan dengan kain tenun sumba Pahikung karena keduanya memiliki ketebalan yang berbeda.

Hasil pengujian tersebut dapat dilihat pada Tabel 1 di bawah ini.

Tabel 1. Karakteristik kain Busana Ready To Wear

\begin{tabular}{cc}
\hline \multicolumn{2}{c}{ Karakteristik Kain } \\
\hline Jenis Anyaman & Turunan keper tulang ikan \\
Tebal Kain & $0,35 \mathrm{~mm}$ \\
Berat Kain & $155,43 \mathrm{~g} / \mathrm{m}^{2}$ \\
Drape Kain & $33,61 \%$ \\
Kekakuan Kain & $11,25 \mathrm{mgCm}$ \\
Kekuatan Tarik (arah lusi) & $33,17 \mathrm{Kg}$ \\
Kekuatan Tarik (arah pakan) & $19 \mathrm{~g}$ \\
\hline
\end{tabular}

\subsection{Perhitungan Biaya Produksi}

Dalam perancangan dan pembuatan busana ready to wear Sumba Pahikung, dibutuhkan biaya produksi yang dirinci pada Tabel 2 dan Tabel 3 berikut ini.

Tabel 2. Perhitungan Harga Pokok Produksi (HPP) Sumba Pahikung 1

\begin{tabular}{|c|c|c|}
\hline No & Keterangan & Harga $(R p)$ \\
\hline 1 & Total biaya bahan baku & 262.500 \\
\hline 2 & Total biaya tenaga kerja & 200.000 \\
\hline 3 & Total biaya packaging & 26.000 \\
\hline 4 & Biaya desain busana & 200.000 \\
\hline & Total HPP & 688.500 \\
\hline & Keuntungan $\mathbf{2 0} \%$ & 137.700 \\
\hline & $\begin{array}{l}\text { J umlah } \\
\text { Harga J ual B usana }\end{array}$ & $\begin{array}{r}826.200 \\
850.000\end{array}$ \\
\hline
\end{tabular}

Tabel 3. Perhitungan Harga Pokok Produksi (HPP) Sumba Pahikung 2

\begin{tabular}{|c|c|c|}
\hline No & Keterangan & Harga $(R p)$ \\
\hline 1 & Total biaya bahan baku & 525.000 \\
\hline 2 & Total biaya tenaga kerja & 150.000 \\
\hline 3 & Total biaya packaging & 26.000 \\
\hline 4 & Biaya desain busana & 200.000 \\
\hline & Total HPP & 901.000 \\
\hline & $\begin{array}{r}\text { Keuntungan } 20 \% \\
\text { J umlah } \\
\text { Harga J ual B usana }\end{array}$ & $\begin{array}{r}180.200 \\
1.081 .200 \\
1.100 .01\end{array}$ \\
\hline
\end{tabular}

\subsection{Survey Busana Ready To Wear Sumba Pahikung}

Survey yang dilakukan untuk mengetahui ketertarikan masyarakat dan menentukan harga produk yang layak untuk busana ready to wear Sumba Pahikung menghasilkan data sebagai berikut. 


\section{INFORMASI SINGKAT RESPONDEN}
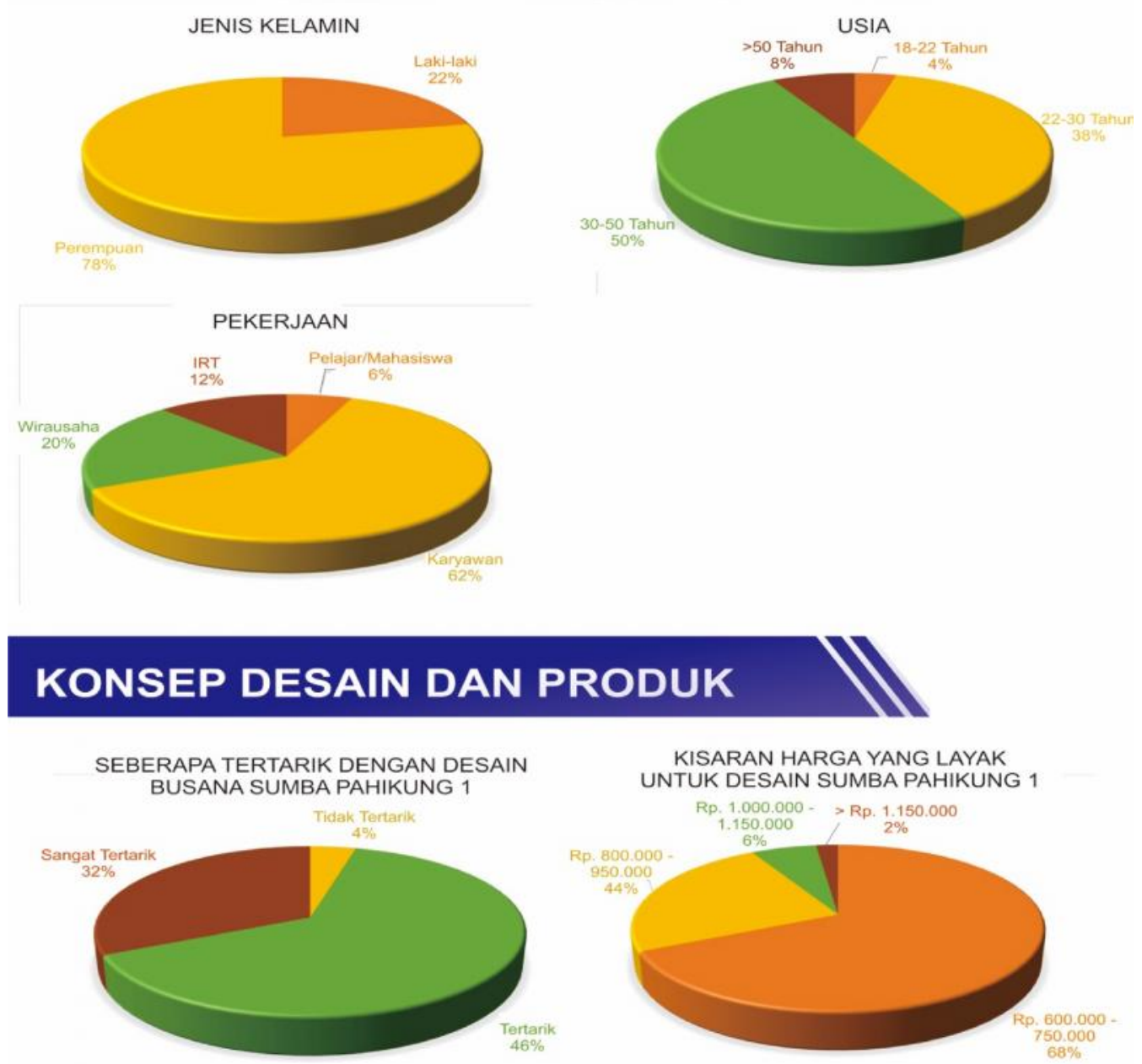

\section{KONSEP DESAIN DAN PRODUK}

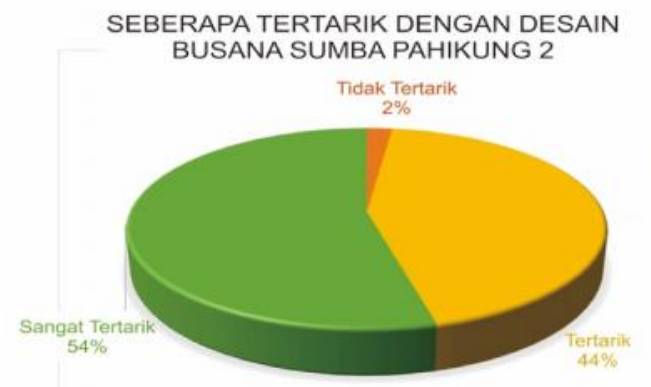

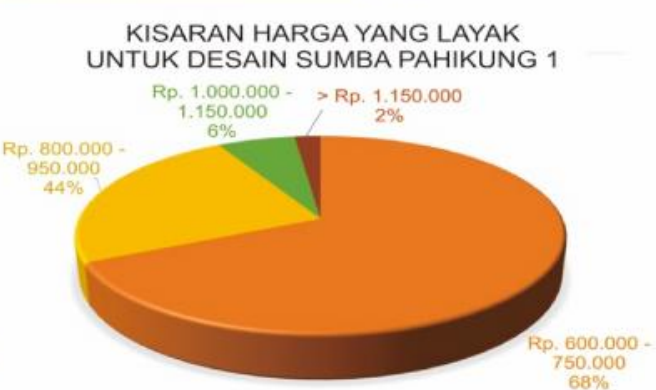

KISARAN HARGA YANG LAYAK

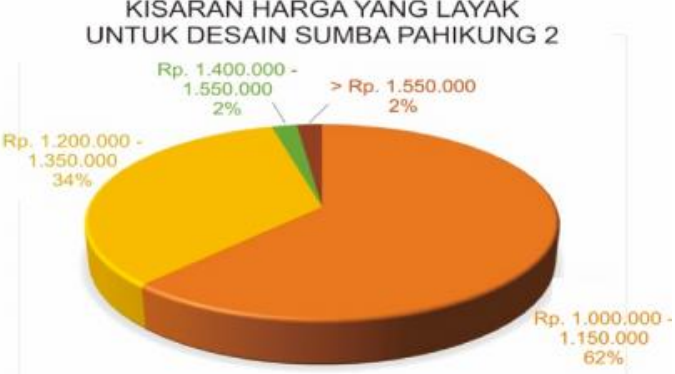

Gambar 5. Diagram Survey Busana Ready To Wear Sumba Pahikung

\subsection{Pembahasan}

Pembuatan rancangan desain busana ready to wear dengan mengaplikasikan tenun, terinspirasi dari keunikan hasil pembuatan tenun dengan teknik lusi tambah yang lebih dikenal dengan nama teknik pahikung di daerah Sumba. Teknik pahikung menghasilkan motif geometris pada satu sisi kain saja, pada sisi lainnya merupakan sebaliknya. Pengaplikasian kain tenun Sumba pahikung pada busana ready to wear merupakan salah satu cara untuk mengenalkan kain tenun Nusantara kepada masyarakat luas melalui produk fashion. Penciptaan rancangan busana juga diinspirasi oleh gaya hidup masyarakat yang menginginkan busana ready to wear atau siap pakai. Busana 
ready to wear lebih diminati oleh masyarakat karena desain yang sederhana dan keunggulan desain busana yang dapat dipadu-padankan dengan berbagai jenis busana casual lainnya. Selain itu faktor harga jual juga mempengaruhi gaya berbelanja pada masyarakat.

Rangkaian desain busana ready to wear yang dibuat menyediakan beberapa macam busana seperti blus, dress, celana panjang, dan kulot. Keberagaman busana tersebut bukan hanya memberi pilihan gaya berbusana kepada masyarakat, namun juga untuk menyesuaikan dengan kesempatan waktu serta kegiatan pemakainya. Desain busana ready to wear tersebut dapat pula digunakan pada aktivitas bekerja sehari-hari, bahkan kesempatan rapat atau pertemuan lainnya. Konsep warna terinpsirasi dari Trend Forcasting 2017-2018 Fashion Greyzone tema Vigilant. Pada tema ini terdapat palet warna berupa warna acajou sebagai warna tenun Sumba Pahikung. Kemudian dipadupadankan dengan warna hangat.

Pada desain Produk Sumba Pahikung 1, kain tenun Sumba Pahikung diletakan secara utuh pada bagian depan busana, sehingga akan menjadi aksentuasi utama. Pada desain Sumba Pahikung 2 , rancangan busana dibuat dengan model dress tanpa lengan yang menempatkan kain tenun pada bagian badan depan. Kedua desain ini memberikan kesan anggun pada pemakai.

Pada setiap desain busana diberikan detail berupa kepang (dilatar belakang tidak dijelaskan kenapa mengangkat kepangan, yang dibahas adalah teknik draping) yang terinspirasi dari tema Vigilant dan di aplikasi pada bagian garis pinggang, bagian dada dan lengan yang bertujuan untuk memperindah busana serta untuk menandakan adanya kesatuan serta keharmonisan busana satu dengan lainnya melalu detail yang diletakan pada busana. Pengerjaan aplikasi kepang dilakukan dengan pengerjaan tangan yaitu degan cara menjahit som atau blind stitch.

Rancangan desain busana ready to wear tersebut memiliki target pasar wanita pekerja / karyawan yang dinamis, dapat melakukan perjalanan pada waktu kerja, maupun menghadapi klien untuk bernegosiasi pada kegiatan merchandiser atau penawaran produk atau jasa, yang biasa dilakukan oleh bagian marketing atau untuk menghadiri acara-acara penting lainnya.

Hasil rancangan busana tersebut dijual dengan harga untuk Produk SumbaPahikung 1 seharga Rp.850.000,00 dan Produk Sumba Pahikung 2 seharga Rp. 1.100.000,00. Harga Sumba Pahikung 1 untuk busana two pieces yang terdiri atasan dan bawahan berupa celana 7/8 yang saat ini banyak digemari, sedangkan Sumba Pahikung 2 merupakan harga untuk calf lenght dress tanpa lengan. Harga jual busana Tugas Akhir didapat dari didapat dari perhitungan biaya produksi setiap baju dengan persentase laba setiap penjual sebesar $20 \%$. Pengambilan persentase laba telah memperhitungkan beberapa aspek seperti inflasi dan biaya pemasaran. Untuk mengumpulkan pendapat khalayak, penelitian ini menggunakan media google form untuk menyebar kuisioner mengenai kelayakan harga yang ditawarkan. Hasil kuisioner akan dapat memotret pendapat masyarakat atas kelayakan harga dari 2 busana etnik Indonesia.

Hasil dari kuisioner yang tersebar pada 50 responden, menunjukkan bahwa $32 \%$ responden menyatakan ketertarikannya terhadap konsep produk dan desain untuk Sumba Pahikung 1, 64\% menyatakan tertarik, dan $4 \%$ menyatakan tidak tertarik. Sedangkan untuk konsep produk dan desain Sumba Pahikung 2, sebanyak 54\% responden menyatakan sangat tertarik, $44 \%$ menyatakan tertarik, dan 2\% menyatakan tidak tertarik. Hal ini menunjukkan bahwa konsep produk dan desain kedua busana ready to wear yang dihasilkan dari kain Tenun Sumba Pahikung diminati dan dapat dirima oleh responden.

Hasil survey juga menunjukkan bahwa sebanyak $68 \%$ responden menentukan kisaran harga yang layak untuk busana Sumba Pahikung 1 sebesar Rp. 600.000 - Rp. 750.000 Sedangkan untuk busana Sumba Pahikung 2, sebanyak $62 \%$ responden menentukan kisaran harga sebesar Rp. 1.000 .000 - Rp. 1.150 .000

Harga yang ditetapkan untuk busana Sumba Pahikung 1 (Rp.850.000) ternyata masih berada di atas penilaian masyarakat, hal ini kemungkinan dapat disebabkan kurangnya pemahaman masyarakat akan tingginya nilai kain tenun etnik Indonesia, dalam hal ini kain tenun Sumba Pahikung per-potongnya. Hal ini karena proses pembuatan yang cukup memakan waktu lama dan keunikan motif tradisional yang membuat harga 1 potong selendang tenun sumba Pahikung mencapai Rp. 400.000. Tetapi harga yang ditetapkan untuk desain Sumba Pahikung 2 (Rp. 
1.100.000) sesuai dengan harga perhitungan produksi yaitu diantara range $1.000 .000-\mathrm{Rp}$. 1.150 .000 .

Dari kedua analisa di atas, kami dapat melihat bahwa desain busana atau selera masyarakat akan berpengaruh terhadap nilai jual dan penilaian khalayak.

\section{KESIMPULAN}

Hasil dari pembuatan busana ready to wear dengan aplikasi kain tenun Sumba Pahikung dapat ditarik kesimpulan sebagai berikut:

1. Pengaplikasian kain tenun Sumba Pahikung diletakan pada bagian atas busana dan dress, rangkaian desain busana ready to wear yang dibuat menyediakan beberapa macam busana seperti blus, dress, celana panjang, dan kulot. Keberagaman busana tersebut bukan hanya memberi pilihan gaya berbusana kepada masyarakat, namun juga untuk menyesuaikan dengan kesempatan waktu serta kegiatan pemakainya.

2. Busana ready to wear dengan aplikasi kain tenun Sumba Pahikung diminati dan dapat diterima oleh masyarakat.

3. Hasil rancangan busana ready to wear tersebut dijual dengan harga untuk Sumba Pahikung 1 seharga Rp.850.000,00, dan Sumba Pahikung 2 seharga Rp. 1.100.000,00.

\section{UCAPAN TERIMA KASIH}

1. Politeknik STTT Bandung melalui UPPM atas support finansialnya sehingga penelitian ini dapat dihasilkan.

2. Ririn Prasetyarini dari Workshop Penjahitan atas bantuannya dalam memproduksi busana sesuai rancangan desain.

3. Samuel Martin dari Lab Evaluasi Fisika Tekstil atas bantuan dalam melakukan evaluasi fisika kain bahan busana Sumba Pahikung.

4. Melsa mahasiswi dari program studi Produksi Garmen yang telah bersedia menjadi model dari busana Sumba Pahikung. 


\section{DAFTAR PUSTAKA}

1. Affendi, Y. (n.d.). Indonesia Indah, Tenunan Indonesia. Jakarta: Yayasan Harapan Kita.

2. Anas, B. (2006). Ikatan Silang Budaya. Art Fabrics.

3. Barnard, M. (2007). Fashion Sebagai Komunikasi. Yogyakarta: Jalasutra.

4. Kartika, S. (2007). Tenun Ikat. Jakarta: Gramedia.

5. Riyanto, A. A. (2003). Teori Busana. Bandung: Yampendo.

6. Widarwati, S. (1993). Desain Busana I. Yoyakarta: IKIP Yoyakarta.

7. Bekraf. Grey Zone Trend Forecasting 2017-2018. Jakarta. IF.

8. http://www.asiantextilestudies.com/pahikung-01.html

9. Furqon. (1999). Statistika Terapan Untuk Penelitian. Bandung: CV. Alfabeta.

10. Dwi Urip Wardoyo. (2016). Analisis Perhitungan Harga Pokok Produksi Dan Penentuan Harga Jual Atas Produk. Jurnal Riset Manajemen dan Bisnis Vol.1, No.2. Jakarta: Fakultas Ekonomi Universitas Islam Attahiriyah. 